\title{
DÜBLIN
}

Technological University Dublin

ARROW@TU Dublin

Articles

School of Manufacturing and Design

Engineering

2018

\section{Daylight characteristics of a polymer dispersed liquid crystal switchable glazing}

\author{
A. Ghosh \\ University of Exeter, United Kingdom \\ Brian Norton \\ Technological University Dublin, brian.norton@tudublin.ie \\ T.K. Mallik \\ University of Exeter, United Kingdom
}

Follow this and additional works at: https://arrow.tudublin.ie/engschmanart

\section{Recommended Citation}

Norton, B., Ghose, A. \& Mallick, T.K. (2018). Daylight Characteristics of a Polymer Dispersed Liquid Crystal Switchable Glazing. Solar Energy Materials and Solar Cells, vol. 174, pp. 572-576. doi: 10.1016/ j.solmat.2017.09.047.

This Article is brought to you for free and open access by the School of Manufacturing and Design Engineering at ARROW@TU Dublin. It has been accepted for inclusion in Articles by an authorized administrator of ARROW@TU Dublin. For more information, please contact arrow.admin@tudublin.ie, aisling.coyne@tudublin.ie, gerard.connolly@tudublin.ie.

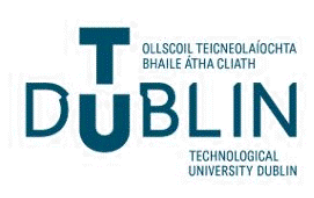




\section{Daylight characteristics of a polymer dispersed liquid crystal switchable glazing}

\section{Aritra Ghosh ${ }^{\mathrm{a}, \mathrm{b}, *}$}

a.ghosh@exeter.ac.ukaritraghosh 9@yahoo.co.in

Brian Norton

Tapas Mallick

aEnvironmental and Sustainability Institute, University of Exeter, PenymPenryn, GornallCornwall, UK

bDublin Energy Lab, Dublin Institute of Feetrogtechnology, DublinDublin, Ireland

*Corresponding author at: Environmental and Sustainability Institute, University of Exeter, Penryn, Cornwall, UK

\section{Abstract}

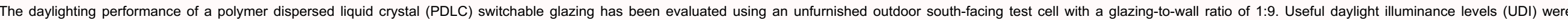

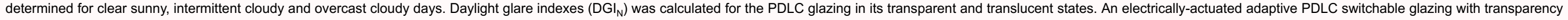
that varied between $27 \%$ and $71 \%$ was able to control daylight glare.

\section{Keywords: adaptiveAdaptive; PDLC; glazingGlazing; daylightDaylight; UDI; glareGlare}

\section{Introduction}

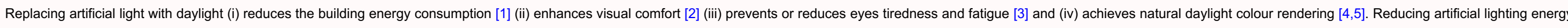
demand in building during the day requires appropriate daylighting design [6-8]. Occupant visual comfort can be maintained via the use of curtains, blinds and adaptive glazings that actively or passively adjust their optical properties [9-11]

Acceptable illuminances for work and study inside a room can vary between 100 and $2000 \mathrm{~lx}$ as shown in Table 1 [12]

\section{Table 1 Acceptability of illumination}

alt-text: Table 1

Illuminance level (Lux)

$\geq 150$
500
500

840-2146 (morning)840-2146.(morning)

782-1278 (afternoon) 782-1278-(afternoon)

700-1800 700-1800-

100-2000 100-2000

Acceptability
Comfort
Comfortable
Comfortable
Comfortable
Comfortable
Comfortable
Useful Daylight Illuminance

\begin{tabular}{|l|l|}
\hline \multicolumn{1}{|c}{ Activity } & \multicolumn{1}{c}{ Reference } \\
\hline Working space & {$[13]$} \\
\hline Office work & {$[14]$} \\
\hline Office work & {$[15]$} \\
\hline Office work & {$[4,5,15]$} \\
\hline Computer work & {$[16]$} \\
\hline Any types of work & {$[12]$} \\
\hline
\end{tabular}

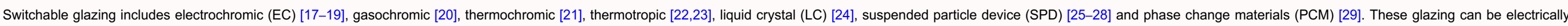




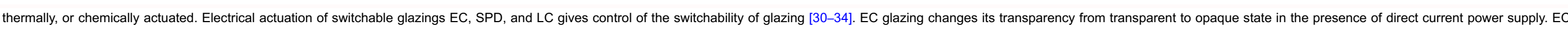

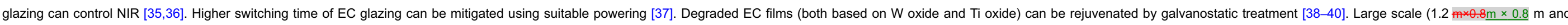

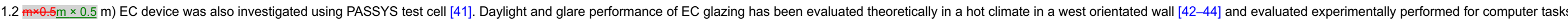

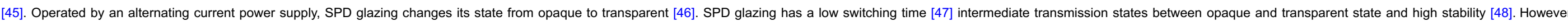

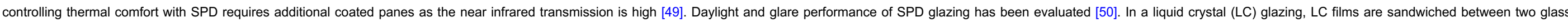

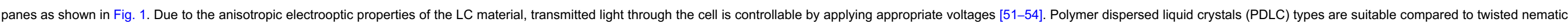

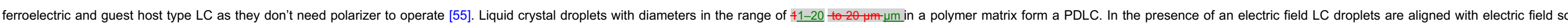
allowing light passes through it. In the absence of an electric field LC droplets orient isotropically, scattering incident beam so becoming white translucent.

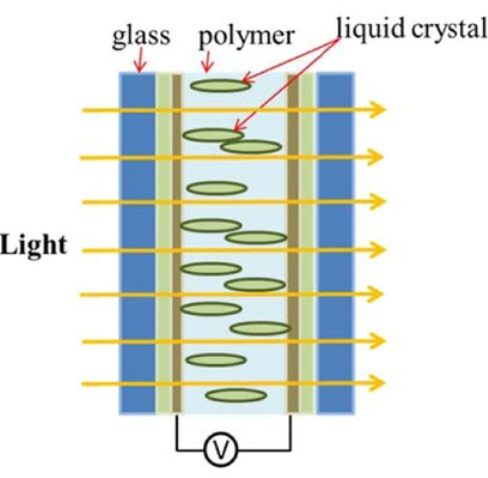

PDLC switch on / transparent ( $71 \%)$

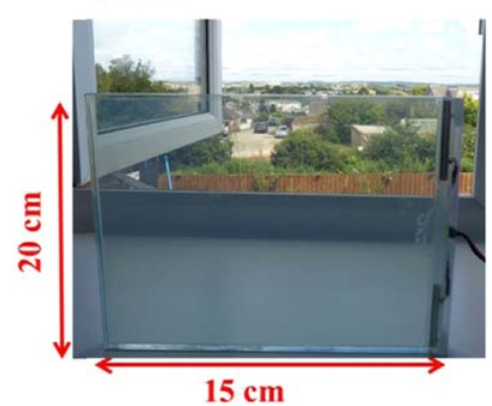

Light

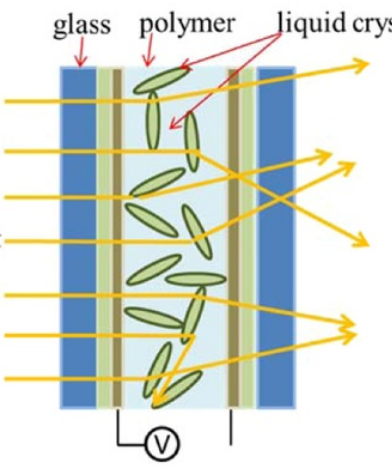

PDLC switch off / translucent

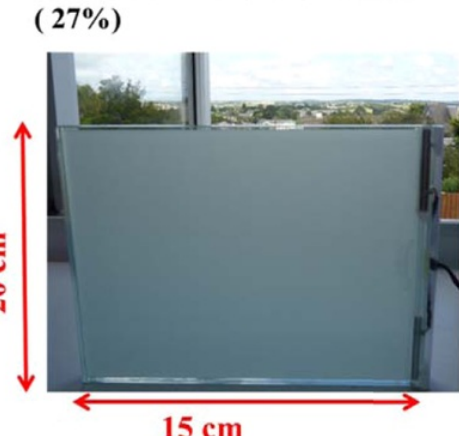

$15 \mathrm{~cm}$

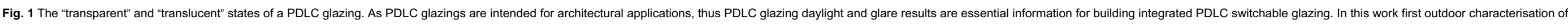
PDLC glazing using test cell was performed to find out its glare and daylight control potential.

\section{alt-text: Fig. 1}

\section{Methodology}

Daylight glare index (DGI) $[56,57]$ has been used to characterise EC glazing $[42,43]$ and for SPD glazing $[50]$ using data from a test cell. The DGI $\left.\right|_{N}$ is given by

$$
D G I_{N}=10 \log _{10} 0.478 \sum_{i=1}^{n} \frac{L_{e x t}^{1.6} \Omega_{p N}^{0.8}}{L_{a d p}+0.07 \omega_{N}^{0.5} L_{\text {win }}}
$$

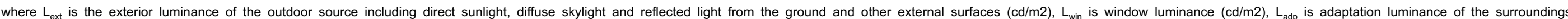

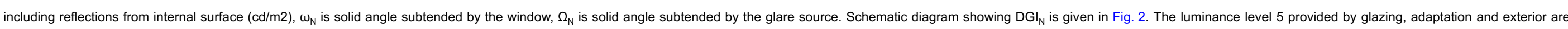




$$
\begin{aligned}
& L_{\text {win }}=\frac{E_{V, w i n}^{i n}}{2 \pi \phi} \\
& L_{\text {adp }}=\frac{E_{V, a d p t}^{i n}}{\pi} \\
& L_{\text {neag }}=\frac{E_{V, \text { neag }}^{\text {in }}}{2(\pi-1)}
\end{aligned}
$$

where

$L_{\text {ext }}=L_{\text {neag }}$

$\omega_{N}=\frac{\left[a b \cos \left(\tan ^{-1} X\right) \cos \left(\tan ^{-1} Y\right)\right]}{d^{2}}$

$\Omega_{N}=2 \pi \phi$
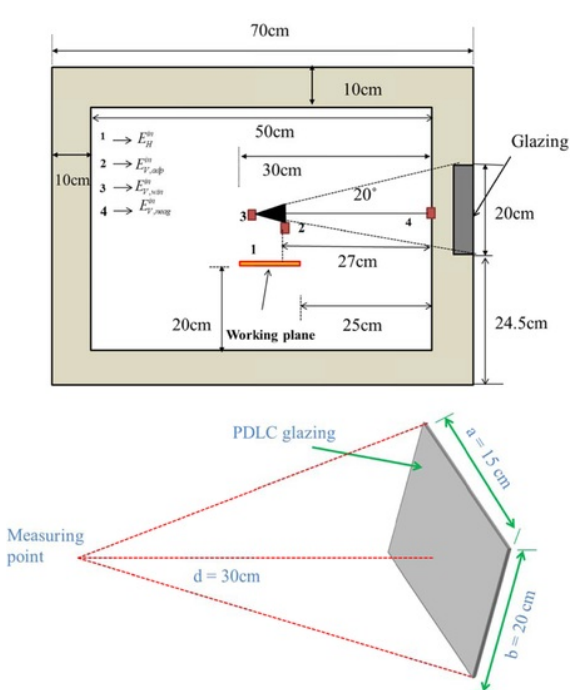

Fig. 2 Experimental set up used to obtain data for the calculation of $\left.D G\right|_{N}$, with configuration factor calculation diagram. alt-text: Fig. 2

The configuration factor $\phi$ was calculated from the Eq. (7) using (Fig. 2)

where

$\phi=\frac{\left(A \tan ^{-1} B+C \tan ^{-1} D\right)}{\pi}$

where

$$
A=\frac{X}{\left[\sqrt{\left(1+X^{2}\right)}\right]}, B=\frac{Y}{\left[\sqrt{\left(1+X^{2}\right)}\right]}, C=\frac{Y}{\left[\sqrt{\left(1+Y^{2}\right)}\right]}, \quad D=\frac{X}{\left[\sqrt{\left(1+Y^{2}\right)}\right]}
$$

$\mathrm{X}$ and $\mathrm{Y}$ can be calculated from Eqs. (8) and (9). 
$a$ is the width of PDLC glazing, $b$ is the height of PDLC glazing and $d$ is the perpendicular distance from the observation place of the centre of glazing as shown in Fig. 2.

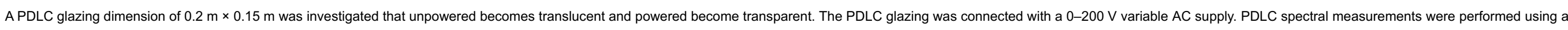
LAMBDA 1050 UV/Vis/NIR Spectrophotometer. Fig. 3 shows the variation of PDLC transmission when "transparent" with $71 \%$ average transmittance and "translucent" with $27 \%$ average transmittance.

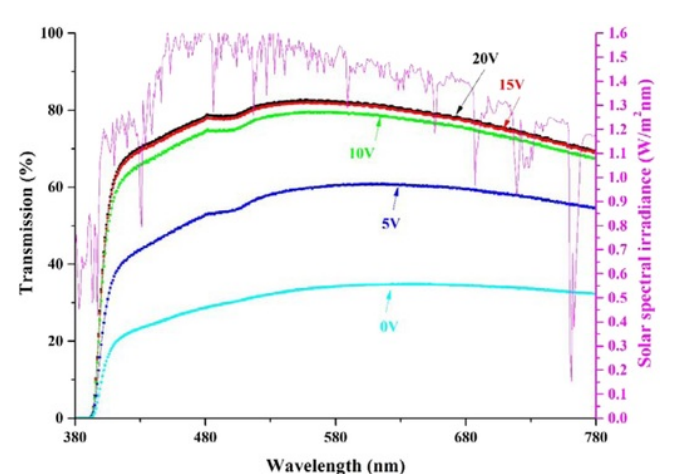

Fig. 3 Voltage dependant luminous transmission of a PDLC glazing in transparent, translucent and intermediate states. alt-text: Fig. 3

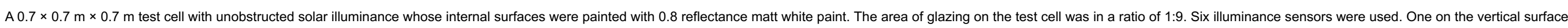

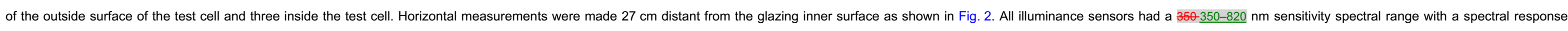

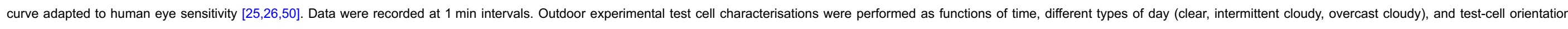

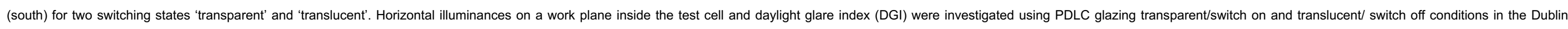
climate $\left(53.3478\left(53.3478^{\circ} \mathrm{N}\right.\right.$ latitude) for three days with different prevailing weather conditions.

\section{Results and discussions}

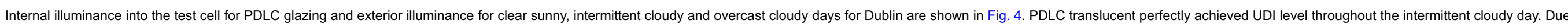
to higher diffuse transmission of PDLC translucent always offered higher UDI level. 


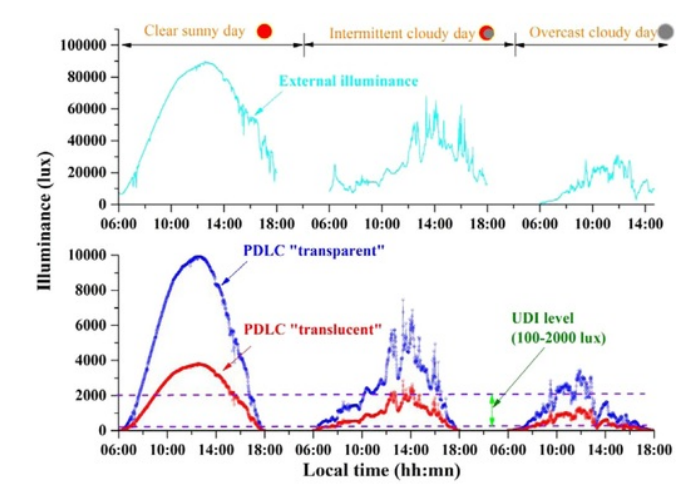

Fig. 4 External illuminance and internal illuminance for south facing PDLC transparent and translucent states for clear sunny, intermittent cloudy and overcast cloudy day in Dublin. alt-text: Fig. 4

Figs. 5-7 show the daylight glare index (DGI $)$ of PDLC glazing for its transparent and translucent state for clear sunny, intermittent cloudy and overcast cloudy sky conditions.

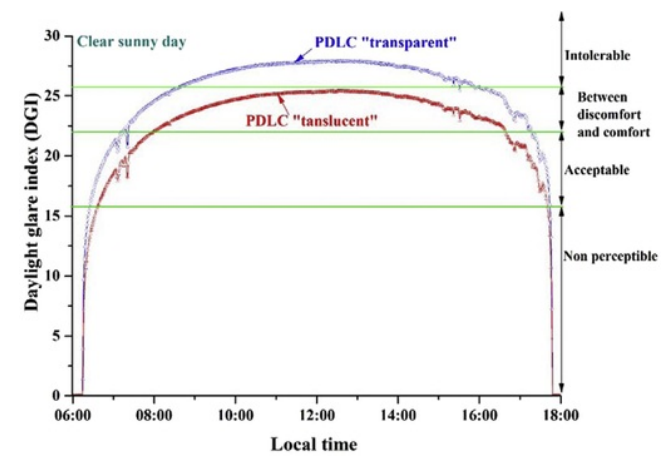

Fig. 5 DGl of PDLC glazing transparent and translucent states for a sunny day in Dublin. alt-text: Fig. 5

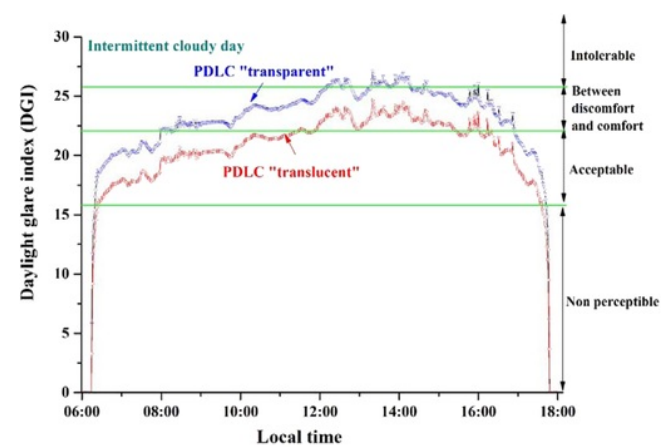

Fig. 6 DGI of PDLC glazing transparent and translucent states for an intermittent cloudy day in Dublin.

alt-text: Fig. 6 


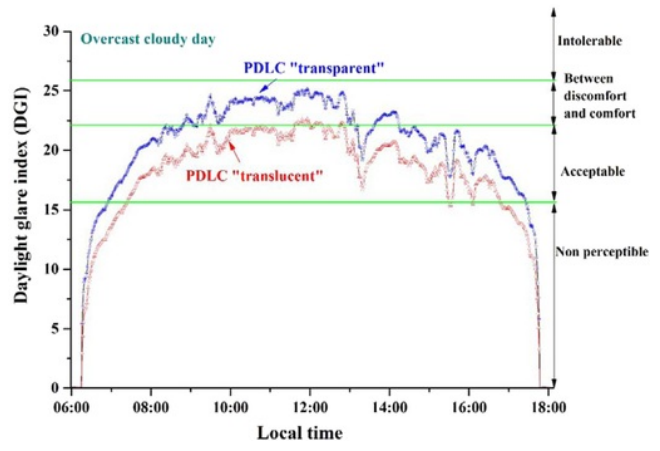

Fig. 7 DGl of PDLC glazing transparent and translucent states for an overcast cloudy day in Dublin. alt-text: Fig. 7

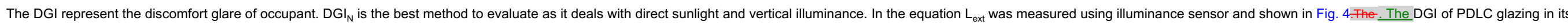
transparent and translucent states was calculated using Eq. (1). The solid angles subtended by the glare source $\left(\Omega_{\mathrm{N}}\right)$ and by the glazing $\left(\omega_{\mathrm{N}}\right)$ were $0.057,0.03 \mathrm{Sr}$ and $0.35 \mathrm{Sr}$ respectively.

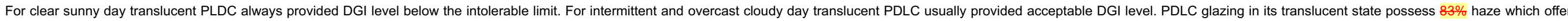

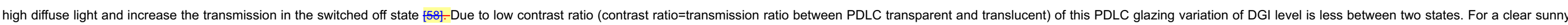

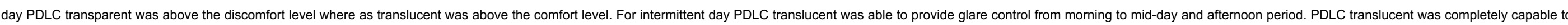
control glare on an overcast cloudy day where as transparent state offered discomfort for short time span.

\section{Conclusion}

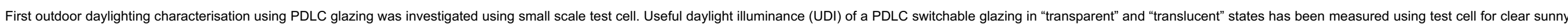

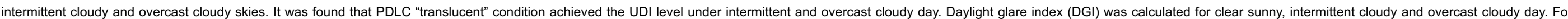

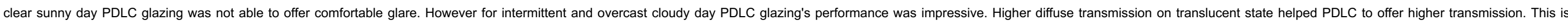

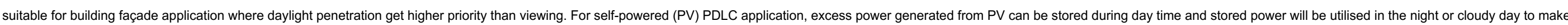
glazing transparent.

\section{References}

[1] D.H. Li, A review of daylight illuminance determinations and energy implications, AppliedAppl. Energy 87, 2010, 2109-2118.

[2] P.J. Littlefair, Prediction of Reflected Solar Dazzlereflected solar dazzle from Stoping Facadessloping facades,

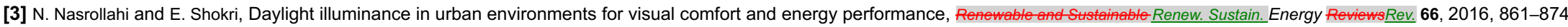

[4] L. Roache, E. Dewey and P. Littlefair, Occupant reaction to daylight in offices,

[5] L. Roache, Summer time performance of an automated lighting and blinds control system, Les. Technol. 34, $2002,11-25$.

[6] M. Bodart and A.D. Herde, Global energy savings in offices buildings by the use of daylighting, Energy ButldingsBuild. 34, 2002, 421-429.

[7] A.D. Galasiu and J.A. Veitch, Occupant preferences and satisfaction with the luminous environment and control systems in daylit offices: a literature review, Energy ButletingBuild. 38, 2006, 728-742.

[8] X. Yu and Y. Su, Daylight availability assessment and its potential energy saving estimation A_a literature review, 2015, 494-503.

[9] F. Favoino, M. Overend and Q. Jin, The optimal thermos-optical properties and energy saving potential of adaptive glazing technologies, AppliedAppl. Energy 156, 2015, 1-15. 
[10] A. Ghosh, B. Norton and A. Duffy, Measured thermal \& daylight performance of an evacuated glazing using an outdoor test cell, AppliedAppl. Energy 177, 2016, 196-203.

[11] B.D. Hatton, I. Wheeldon, M.J. Hancock, M. Kolle, J. Aizenberg and D.E. Ingber, An artificial vasculature for adaptive thermal control of windows, SolarSol. Energy \#laterials and Solar Mater. Sol. Cells 117, 2013 , 429-436.

[12] A. Nabil and J. Mardaljevic, Useful daylight illuminances: a replacement for daylight factors, Energy

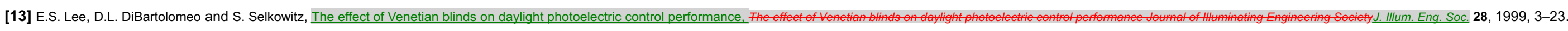

[14] Chartered Institute of Building Services Engineers (CIBSE)(CIBSE), 1999. Daylighting and window design (design. Lighting guide 10.

[15] E. Vine, E. Lee, R. Clear, D. DiBartolomeo and S. Selkowitz, Office workers response to an automated venetian blind and electric lighting system—a pilot study, Energy and BuildingBuild. 28, $1998,205-218$.

[16] C.F. Reinhart, Effects of interior design on the daylight availability in open plan offices, 2002 , 1-12.

[17] C.G. Granqvist, Electrochromic tungsten oxide films: review of progress 1993-1998, SolatSol. Energy Alaterials and Sotar Mater. Sol. Cells 60, 2000, 201-262.

[18] C.G. Granqvist, Oxide electrochromics: an introduction to devices and materials, SolarSol. Energy Materials and Solar Mater. Sol. Cells 99, 2012, 1-13.

[19] C.G. Granqvist and V. Wittwer, Materials for solar energy conversion: an overview, SolarSol. Energy Alaterials and Solar Mater. Sol. Cells 54, $1998,39-48$.

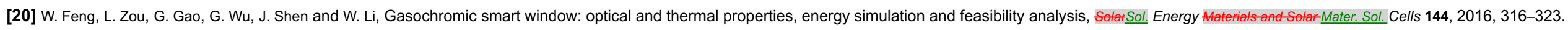

[21] V. Costanzo, G. Evola and L. Marletta, Thermal and visual performance of real and theoretical thermochromic glazing solutions for office buildings, soltrsol. Energy Hateriats and Solar-Mater. Sol. Cells 149, $2016,110-120$.

[22] O. Muehling, A. Seeboth, T. Haeusler, R. Ruhmann, E. Potechius and R. Vetter, Variable solar control using thermotropic core/shell particles, Solar:SOl. Energy \#taterials and Sotar Mater. Sol. Cells 93, 2009, 1510-1517.

[23] P. Nitz and H. Hartwig, Solar control with thermotropic layers, Solar Sol. Energy 79, 2005, 573-582.

[24] D.J. Gardiner, S.M. Morris and H.J. Coles, High-efficiency multi stable switchable glazing using smectic A liquid crystals, sotarSol. Energy \#tateriats \& Sotar Mater. Sol. Cells 93, 2009, 301-306.

[25] A. Ghosh, B. Norton and A. Duffy, Measured overall heat transfer coefficient of a suspended particle device switchable glazing, AppliedAppl. Energy 159, 2015, 362-369.

[26] A. Ghosh, B. Norton and A. Duffy, Behaviour of a SPD switchable glazing in an outdoor test cell with heat removal under varying weather conditions, AppliedAppl. Energy 180, 2016, 695-706.

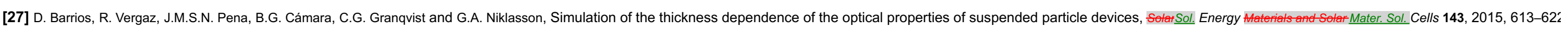

[28] R. Vergaz, J.M.S.N. Pena, D. Barrios, C. Va'zquez and P.C. Lallana, Modelling and electro-optical testing of suspended particle devices, Sotarsol. Energy \#ateriats and Sotar Mater. Sol. Cells 92, 2008, 1483-1487.

[29] F. Goia, M. Zinzi, E. Carnielo and V. Serra, Spectral and angular solar properties of a PCM-filled double glazing unit, Energy BuildingBuild. 87, 2015, 302-312.

[30] A. Ghosh, B. Norton and A. Duffy, Effect of atmospheric transmittance on performance of adaptive SPD-vacuum switchable glazing, Solatsol. Energy \#taterials and Solar Mater. Sol. Cells 161, $2017,424-431$.

[31] A. Ghosh, B. Norton and A. Duffy, Effect of sky clearness index on transmission of evacuated (vacuum) glazing, Energy 105, 2017, 160-166.

[32] A. Ghosh, B. Norton and A. Duffy, Effect of sky conditions on light transmission through a suspended particle device switchable glazing, Solar Sol. Energy \#latials and Solar-Mater. Sol. Cells 160, 2017, 134-140.

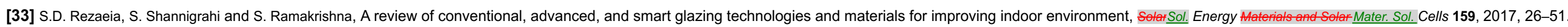

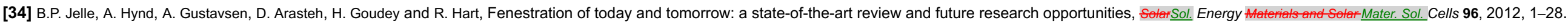

[35] J.S. Hale and J.A. Woollam, Prospects of IR emissivity control using electrochromic structures, Thin Solid Films 339, 1999, 174-180.

[36] A.P. Schuster, D. Nguyen and O. Caporaletti, Solid state electrochromic infrared switchable windows, SolarSol. Energy HateriatsMater. 13, 1986, 153-160.

[37] J.D. Engfeldt, P. Georen, C. Lagergren and G. Lindbergh, Methodology for measuring current distribution effects in electrochromic smart windows, Appl. Opt. 50, 2011, 5639, https://doi.org/10.1364/AO.50.005639. 


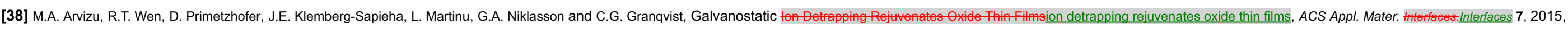
26387-26390.

[39] R.-T. Wen, C.G. Granqvist and G.A. Niklasson, Eliminating degradation and uncovering ion-trapping dynamics in electrochromic WO3 thin films, Nat. Mater. 14, $2015,996-1001$.

[40] R.T. Wen, G.A. Niklasson and C.G. Granqvist, Sustainable Rejuvenationrejuvenation of Electrochromieelectrochromic WO3 Filmsfilms, ACS Appl. Mater. Interfaces.Interfaces 7, 2015 , $28100-28104$.

[41] A. Kraft and M. Rottmann, Properties, performance and current status of the laminated electrochromic glass of Gesimat, Sol. Energy Mater. Sol. Gells.Cells 93, 2009, 2088-2092.

[42] A. Piccolo, A. Pennisi and F. Simone, Daylighting performance of an electrochromic window in a small scale test-cell, Sol. Energy 83, $2009,832-844$.

[43] A. Piccolo and F. Simone, Effect of switchable glazing on discomfort glare from windows, Building Envirantild. Environ. 44, 2009, 1171-1180.

[44] M. Moeck, E.S. Lee, M.D. Rubin, R.T. Sullivan and S.E. Selkowitz, Visual quality assessment of electrochromic and conventional glazings, Sotarsol. Energy \#tateriats \& Sotar Mater. Sol. Cells 54, 1998, 157-164.

[45] E.S. Lee, D.L. DiBartolomeo and S.E. Selkowitz, Daylighting control performance of a thin-film ceramic electrochromic window: field study results, Energy

[46] A. Ghosh, B. Norton and A. Duffy, First outdoor characterisation of a PV powered suspended particle device switchable glazing, Sotar Sol. Energy Atateriats \& Sotar-Mater. Sol. Cells 157, 2016, 1-9.

[47] A. Ghosh and B. Norton, Durability of switching behaviour after outdoor exposure for a suspended particle device switchable glazing, Sotarsol. Energy \#ateriats and Solar Mater. Sol. Cells 163, 2017, 178-184.

[48] A. Ghosh and B. Norton, Interior colour rendering of daylight transmitted through a suspended particle device switchable glazing, Solar Sol. Energy thateriats and Solar Mater. Sol. Cells 163, 2017, 218-223.

[49] A. Ghosh, B. Norton and A. Duffy, Measured thermal performance of a combined suspended particle switchable device evacuated glazing, AppliedAppl. Energy 169, 2016, 469-480.

[50] A. Ghosh, B. Norton and A. Duffy, Daylighting performance and glare calculation of a suspended particle device switchable glazing, soter Sol. Energy 132, 2016, 114-128.

[51] Y. Ajhaneyulu and D.W. Yoon, A PCGH liquid crystal window to control solar energy, Solar Energyenergy, Aateriatsolar Energy Mater. 14, 1986, $223-232$.

[52] C.M. Lampert, Large-area smart glass and integrated photovoltaics, Solar Sol. Energy thateriats and Sotar Mater. Sol. Cells 76, 2003, 489-499.

[53] C.M. Lampert, Optical-switching technology for glazings, Thin Solid Films 236, 1993, 6-13.

[54] C.M. Lampert, Smart switchable glazing for solar energy and daylight control, SolarSol. Energy Haterials and Solaf Mater. Sol. Cells 52, 1998, $207-221$.

[55] G. Macrelli, Optical charcaterizationcharacterization of commercial large area liquid crystal devices, SolarSol. Energy Alaterials and Solar cellsMater. Sol. Cells 39, 1995, 123-131.

[56] A.A. Nazzal, A new daylight glare evaluation method Introduction of the monitoring protocol and calculation method, Energy ButildingBuild. 33, 2001, 257-265.

[57] A.A. Nazzal, A new evaluation method for daylight discomfort glare, Ind. Ergon. 35, 2005, 295-306.

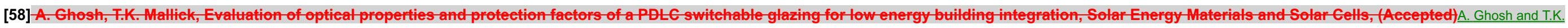
Mallick, Evaluation of optical properties and protection factors of a PDLC switchable glazing for low energy building integration, Sol. Energy Mater. Sol. Cells 2017, (In press).

Highlights

- Daylight indices and factors have been calculated for a PDLC glazing "translucent" and "transparent" states.

- Voltage dentependant transmission of a PDLC glazing is reported. 


\section{Queries and Answers}

Query:

Please confirm that given names and surnames have been identified correctly and are presented in the desired order, and please carefully verify the spelling of all authors.

Answer: Tapas Mallick will be T.K. Mallick

Query:

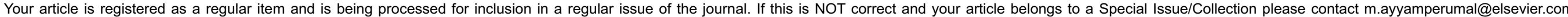
immediately prior to returning your corrections.

Answer: Yes this is regular item and regular issue

Query:

Please validate if the address for the corresponding author that has been added here is correct.

Answer: All are correct

Query:

Highlights should consist of $3-5$ bullet points. There are less bullet points provided. Please edit the highlights to meet the requirement.

Answer: Experiment was performed using outdoor test cell

Query:

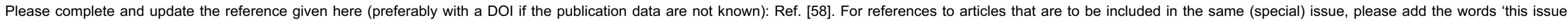
wherever this occurs in the list and, if appropriate, in the text.

Answer: please delete this 